Studia Slavica Savariensia 2018. 1-2. 72-78

DOI: $10.17668 /$ SSS.2018.1-2.72

\author{
Dudás Mária \\ (Budapest, Magyarország)
}

\title{
AZ ÖRÖM KIFEJEZÉSE A MAGYAR ÉS BOLGÁR FRAZEOLÓGIÁBAN
}

\begin{abstract}
Emotions are almost impossible to be expressed by the means of language. Words can denote thoughts only, i. e. words describe reactions, behaviors accompanying the given emotion that is normally expressed by non verbal communication. Joy is the only emotion with positive polarity among basic emotions. Both Hungarian and Bulgarian language have expressions related to human appearance showing signs of joy, especially on the face and in the eyes. Heart and soul are the places filled by joy. Expressing joy is accompanied by motion in both languages, the Hungarian caper with joy, somersault, dance, the Bulgarian fly, cry. These phrasemes warn also that too much joy can result in sadness. The Hungarian language has many metaphors, it expresses even sorrow by using JOY in an opposite meaning. In Bulgarian joy is an emotion to be suppressed.
\end{abstract}

Keywords: joy, sorrow, emotion, metaphor

A kognitív nyelvtudomány azt a nézetet képviseli, mely szerint az a fogalom rendszer, amely meghatározza az objektív valóságban észlelt entitásokat, metaforikus jellegü. A metaforák biztosítják az egyik fogalomnak a másik kategóriáiban történő megértését. A metaforák bázisán jön létre a fogalmak alapvető készlete, amely elsősorban az emberi érzelmekre érvényes (BAŃCZEROWSKI 2005: 202). Az érzelmek (emóciók) nagyon fontos szerepet játszanak a lelki életünkben és hatással vannak figyelmi teljesítményünkre, gondolatainkra, viszonyulásainkra, kapcsolatainkra. Nehéz és talán lehetetlen felsorolni az érzelem szerepét az emberi viselkedésben. Érzelmeinket szubjektív és objektív tényezők egyaránt befolyásolják. Az érzelmek rendkívül összetettek, több tényezö együttes kölcsönhatását jelentik. Ezek lehetnek belső testi válaszok, elsősorban a vegetatív idegrendszer reakciói. Kognitív kiértékelés által létrejövő vélekedés, amelynek tartalma, hogy egy negatív vagy pozitív esemény megy végbe.

Polaritás szerint megkülönböztetünk kellemes vagy pozitív érzéseket, valamint kellemetlen vagy negatív érzéseket. Az érzelmek skálája nagyon színes, amelyek közül ki kell emelni az egyetemes vagy alapérzelmeket, amelyek minden kultúrában megtalálhatók és felismerhetők: harag, félelem, undor, meglepődés, szomorúság és öröm (PSZICHOLÓGIAI). 
Az érzelmek olyan jelenségek, amelyeket nem lehet a nyelv segítségével kifejezni. A szavakban csak a gondolatainkat tudjuk rögzíteni, azaz szavakkal igyekszünk megnevezni azokat a fiziológiai reakciókat, cselekvéseket és viselkedési formákat, amelyek az általunk átélt érzelmet kísérik, és amelyek általában a nem verbális kommunikációban jutnak kifejezésre (BARÁTKA 2014).

Az öröm az alapérzelmek egyetlen pozitív polaritású alapérzelme. A magyar nyelv frazeológiai készletében nagy számban megtalálható.

Barátka tanulmányában azt vizsgálja, hogy néz ki és hogyan viselkedik a magyar, ha boldog. A boldogság univerzális kifejezése elsősorban az ember külsejében mutatkozik meg. Elolvad a boldogságtól, aki szemmel láthatóan nagy boldogságot érez, illetve sugárzik róla a boldogság. Az ember arcán általában tükröződik az általa épp átélt érzelem, vagyis az arcára van írva pl. $a$ boldogság, vagy sugárzik valakinek az arca a boldogságtól. A boldog ember arckifejezése derüssé válik, akinek az örömtől felderül [felragyog] az arca. A szemnek is jelentős szerepe van az érzelmek kifejezésében: árad valakinek a szeméböl a boldogság; kigyúl valakinek a szeme; illetve kigyúl a fény valakinek a szemében, ami azt jelenti, hogy ragyogni, csillogni kezd valakinek a szeme, vagyis boldogság tükröződik a tekintetében. A példák arra utalnak, hogy a fény metaforája alapvető szerepet játszik a boldogság megjelenésében, hiszen a szem úgy mutatkozik meg, mint egy ragyogó tárgy, amelyböl sugárzik a fény (BARÁTKA 2014). A mosolygás is az öröm egy újabb jele, mert hát fülig ér a szája annak, aki nagyon boldog.

Az öröm és boldogság kifejezését féktelen ugrálás is kísérheti: majd a plafonig ugrik [örömében]. Az öröm az ugráláson kívül olyan mozgásformák kiváltója lehet még, mint a cigánykereket hány [örömében]; bukfencet hány [örömében]. Az olyan erös érzelmi állapot, mint az öröm, valamint a türelmetlenség is kiváltó oka lehet annak, hogy valaki majd kiugrik vagy majd kibújik a böréböl. Egyes helyzetekben az ember örömében akár táncra is perdülhet, vagyis kánkánt jár, illetve kánkánt táncol örömében. Miért kánkánt táncol a magyar? Talán magyarázatot ad erre, hogy a kánkán magasra dobált lábbal járt gyors ritmusú tánc.

A víz, a hullámok gyakran a boldogság konvencionális metaforái. Az, aki nagyon örül valaminek, általában úszik a boldogságban. Az érzés elönti az embert: elönt valakit a boldogság, megállíthatatlanul árad valakiben a boldogság, de mint ahogy a hullám jön, majd el is megy, úgy a boldogság is véget érhet, elúszik a boldogság.

A szív és a lélek olyan hely, ahol érvényesül, ahol kibontakozik a boldogság, hiszen arról, aki nagyon boldog, vagy akit boldogság tölt el, azt mondjuk, hogy dagad a szive, vagy megmelegedik a szive. Annak, aki boldog, repes a szive [a lelke] örömében. A repes ige jelentése: „szárnyas állat, föleg madár, ide-oda repdes, szálldos, csapong” vagy „csecsemő, kisgyermek játékos örömében, izgatott vágyakozásában karját nyújtja vki, vmi felé”. Ezekben a példákban ismét a mozgás kapcsolódik az öröm kifejezéséhez. A szív meg is 
telhet boldogsággal, vagyis csordultig van a szive boldogsággal. A boldogság olyan érzelem, amely hirtelen kellemes lelki élmény hatására elönti az embert, ekkor nagyot dobban [megdobban] valakinek a szive, a boldogság betölti valakinek a szivét.

$\mathrm{Az}$ örömhöz a könnyedség, a légiesség kapcsolható, mint fizikai állapotjellemző. A madarak fent szállnak az égen, könnyedek, légiesek, mint a boldog ember. Aki örül, azzal madarat lehet fogatni. Sirisaka Andor közmondásgyüjteménye szerint ez csak csendes, jó természetü emberre mondható. Megemlít azonban egy másik jelentést is, mely szerint oly kész és engedelmes valaki, hogy jó kedvében mindent megtenne a másikért. Nagy Péter szerint ez egy közismert, ma is használatos közmondás, amelynek eredetén, motivációján nem nagyon gondolkodunk el. Szerinte azt feltételezzük, hogy tősgyökeres, eredeti magyar szólás: itthon keletkezett, abban az időben, amikor a madarászás még széles körben üzött foglalkozás volt. Nagy Péter azonban Chrétien de Troyes hőskölteményében is rátalált a közmondásra, melyet ő így fordított: „A király maga mellé ültette őt, megcsókolta és megcsókolta Guivret-t is. Karját Enyde nyaka köré fonta és nagy örömmel csókolgatja. A királyné sem habozott megcsókolni Erecet és Enyde-et; madarat lehetett volna fogatni vele, akkora volt az öröme". Nagy a közmondás eredetét kutatva állítja, hogy a 12. sz.-i francia és a 16. sz.-i magyar előfordulás arra enged következtetni, hogy valószínüleg a franciából kerülhetett a magyarba a szólás, és míg a franciáknál szinte a madarászmesterséggel együtt kihalt a nyelvből, a magyar nyelv megőrizte. Két kérdést fogalmaz meg kutatásában. Hogyan került a francia szólás át a magyar nyelvbe? Szerinte bizonyos, hogy ha onnan került hozzánk, akkor ez a középkor folyamán zajlott le, hiszen akkor volt a legsürübb a két udvar közötti érintkezés. Mindenesetre sokkal valószínübb, hogy onnan került hozzánk, mint fordítva. A másik kérdés, amelyre keresi a választ, hogy mi lehet az oka annak, hogy a "jókedv" és a "madarász" ilyen hosszú időn át, mondhatni szinonimák az európai nyelvekben (NAGY 1999: 205). A magyar nyelvben azonban nemcsak madarat, hanem nyulat is lehet fogatni azzal, akinek nagyon jókedve van, és bármire rá lehet venni örömében. A különbség a jelentésben, hogy a nyúl inkább a jókedvet szimbolizálja. Nyulat foghatsz vele, annyira jókedvü.

Az öröm durva kifejezése bizalmas és fesztelen környezetben a földhöz veri a fenekét [a seggét] szólással lehetséges. A szólásnak több jelentése is van. Az első, hogy nagyon örül, a másik, hogy akkor sem történik meg, még ha földhöz veri a fenekét [a seggét]. Robin Cook az orvosi krimik egyik nagy mestere Gyilkos terápia címü regényében így ír: „Louie nem veri majd a földhöz a fenekét, ha megmondjuk neki, mit derítettünk ki az esetről és Laurie Montgomery-Stapletonról ", vagyis nem fog örülni.

A második jelentés még a magyar politikusok beszédében is felbukkan: „A következő Orbán-kormány akkor sem fog mentességet biztosítani a Benes-

\footnotetext{
${ }^{1}$ https://books.google.hu/books?isbn=9633573181
} 
dekrétumok kapcsán Csehország számára, ha az unió a földhöz veri a fenekét" - jelentette ki Semjén Zsolt ${ }^{2}$, a KDNP elnöke 2009. novemberében Hatvanban egy lakossági fórumot megelőző sajtóbeszélgetésen.

Van, aki úgy örül, hogy azt se(m) tudja, hova tegyen/hova legyen [örömében]. Az öröm megélésnek olyan foka ez, hogy egy pillanatra minden érzékünket elveszítjük. Ezen kívül, aki nagyon boldog, vagy nagy boldogságot érez, az a hetedik mennyországban érzi magát. Az alig tud hova lenni kifejezést akkor használjuk, amikor örömöt, esetleg izgatottságot, kevélységet, bánatot vagy szomorúságot érez az ember. Bőrünk gátat, akadályt szab a teljes boldogság megéléséhez: örömében börében is alig fér, illetve majd kibújik [kiugrik] böréböl, de lehet akár türelmetlenségében, izgatottságában, bosszúságában, dühében. Az ájulás is kerülgetheti az embert, hiszen majd eszméletét veszti az örömtöl, sőt ha fokozzuk, már magánkívül van örömében, amikor a belülről kifelé áradó pozitív érzés teljesen kitör belőlünk.

A boldogságot tehát a leggyakrabban mozgást jelentő igékkel egészítjük ki: maga alá esik az, aki nagyon örül.

A boldogság egy pillanatnyi érzés is lehet, amely elönt minket. Elönt a boldogság [az öröm; a görögtüz]. A pozitív érzéseken túl elönthet még a félelem, a gyász, vagy akár a bizonyosság is.

Az öröm azonban sokszor együtt jár az ürömmel, a szomorúsággal. Vigyázni kell, a túlzásba vitt öröm nem jelent jót. Öröm, üröm: csak egy betüben különböznek, figyelmeztet a magyar. Öröm ürömmel jár; nincsen öröm üröm nélkül vagy nincsen rózsa tövis nélkül, amikor az örömbe bánat vegyül, hiszen nincs az életben tökéletes öröm, zavartalan boldogság. Örömnek gyakran szomorúság a vége; drágán szerzett öröm, hamar leszen üröm; szomorúsággal jár az öröm; pénteki öröm, vasárnapi üröm, sőt a nagy öröm is megölheti az embert.

A magyar nyelv hasonlatokat használ a színek, tulajdonságok, az érzelmek kifejezésére. Örül, mint a férjhez menö lány; örül [neki], mint gyermek a játéknak; mint gyermek a bábnak „mézeskalácsnak”; mint a gyermek a lépes madárnak ,vásárfiának; mint malac a makknak; mint a szomjú szarvas a forrásnak; mint a tücsök a harmatnak; mint a vizbe esett hal; mint éh ló az abraknak; mint ki búzáját eladta.

Nagyon örül egy csekélységnek kifejezése a vaksághoz kacsolódik: örül [neki], mint vak a garasnak; mint vak koldus a fagarasnak. Vak koldus is örül, ha patkóra talál. Ügyetlen embernek is kedvez néha a szerencse, együgyü ember is rátalálhat olykor a helyes megoldásra. Lefitymálóan mondják ügyetlen emberre, akinek véletlenül, kivételesen sikerült valami: vak is lelt egy patkót, örült neki, hogy vas volt.

A hasonlatok ironikus, gúnyos kifejezései lehetnek az öröm ellenkezőjének, ha valaki kétségbe van esve: örül [olyan (jó) kedve van v. úgy vigad v. vígan él], mint akinek a háza ég (, maga meg benne szorult). Ha szomorú, örül, mint

\footnotetext{
${ }^{2}$ http://propeller.hu/itthon/829015-akkor-sem-ha-az-unio-foldhoz
} 
akinek pénze nincs. Ha csapdába került, örül, mint a fogóba esett egér; mint kalitkában a csizike.

Arra, hogy milyen az öröm a bolgár nyelvben a frazeológia megadja a választ. Lehet „édes”, сладка радост és lehet „heves, viharos” érzelem: бурна padocm. Az öröm a bolgár nyelvben is megmutatkozik a külső megjelenésben. Főként a szemben tükröződik, ha valami jó dolog történik, valami a kedvünkre van, akkor az „megörvendezteti a szemet, a szememet”, vagyis радва окото; радва ми окото. Akár „gyógyír, kenőcs is lehet a szemre”, azaz мехлем за очите. Amikor az öröm akkora, hogy elszorul a szív, „sírunk örömünkben”, плача от радост.

A szívben és a lélekben oldódik fel, ,a lelkem [a szívem] mélyén” в дъното на душата си [на сърието си]. A nagy öröm „,megnyitja a lelket”, отваря ми се душата. Mindezek után már ,jó a lelkemnek”, хубаво ми е на душата.

A hatalmas örömtől az ember szinte „nincs magánál”, не съм на себе си от радостma. Továbbfokozva „megőrül az örömtől”, луд съм от радост.

A bolgár nyelvben is kísérheti kényszeres mozgás az öröm kifejezését. Van aki „ugrál örömében”, скача от радост; van, aki „repül örömében v. boldogságában", летя от радост; летя от щастие. A magyarhoz hasonlón a bolgár is „repdes boldogságában”, пърхам от щастие.

A nevetés és a boldogság lehet olyan fokú, hogy „sárga lesz a nadrágja az élvezettöl [az örömtöl]", жълт съм на гащите от кеф [от радост].

A bolgár nyelvre nem jellemző a hasonlatok használata, az öröm kifejezésére azonban a következőket találtuk. „Örül, mint az átfogyott [ember] a napnak”, радва се като помръзнал на слънще; „megörült, mint az árva a napnak”, зарадвал се като сираче на слъние; ironikusan „örül, mint a mi kutyánk a szomszéd szukájának", радва се като нашето куче на комшийската кучка. Boldogságában ,vigyorog, mintha az apja kancái megellettek volna”, хили се, сякаш са се ожребили бащините му кобили.

$\mathrm{Az}$ örömhöz a bolgár nyelvben is kapcsolódik a szomorúság, a fájdalom. „Az öröm és a bánat együtt járnak”, радостта и скръбта заедно ходят; „megosztom az örömöt és a bánatot”, деля радости и скръби; „örömön és ínségen keresztül”, през радости и неволи, tartja a bolgár.

A bolgár ember sajátossága, hogy az örömöt úgy éli meg, mint egy olyan érzés, amelyet el kell fojtani. Овладях радостта си „úrrá lettem az örömömön". A bolgár ember azonban nemcsak az örömét leplezi és küzdi le, hanem az eufóriáját, lelkesedését, elragadtatását, diadalát, овладях еуфорията си, ентусиазма си, възторга си, екстаза си, триумфа си.

Végül a bolgár arra is képes, hogy „megülje valaki örömét”, убивам радостта на някого.

Az öröm kifejezésének módjában a két nyelv frazeológiai készlete egyezéseket mutat. Ennek legfőbb magyarázata, hogy az alap vagy egyetemes érzelmek kifejezése hasonló a világ szinte minden népénél, ami ezeknek az 
érzelmeknek a felismerésében támpontot jelent. Az érzelemkifejezést az öröklött tényezők mellett a kulturális és egyéni tényezők is befolyásolják, ami a frazeológiában megjelenő különbségek okára világít rá. A magyar és a bolgár nyelvben az ember külseje árulkodó lehet az érzelmeit tekintve. A boldogság meglátszik az arcon és a szemben. Leggyakrabban a sugároz, fénylik, ragyog, felderül igék fejezik ki az örömöt a magyarban, míg a bolgárban az öröm a szem boldogságának forrása. Közös pontként a fény metaforáját kell kiemelni. A következő kapcsolódási pont az öröm megnyilvánulása valamilyen mozgás formájában. Az emberek föként ugrálnak, táncolnak örömükben. Míg a magyar ember bukfencet vagy cigánykereket hány, addig a bolgár ember inkább repül, repdes örömében. Mind a két nyelvben megtaláljuk a szívet és a lelket, mint helyet, ahol a boldogságot érezzük, és amelyek telítődnek boldogsággal. A boldogság és az öröm indikálhatja, hogy az ember szinte már nincs magánál vagy esetleg majdnem eszméletét veszti az érzelem megélése során.

Mind a két nyelvben a boldogság és a szomorúság összekapcsolódik. Gyakran együtt járnak, vagy figyelmeztetéseket találunk arra, hogy a túl nagy öröm bánathoz vezethet.

A magyar nyelvre jellemző, hogy a boldogságot a vízhez hasonlítjuk. Jön, elönt vagy megárad, aztán elúszik. A magyar annyira könnyed örömében, hogy el akarja kapni a madarat vagy a nyulat. Amikor boldog, nem találja helyét, nem fér a bőrébe, de egy pillanatra akár a mennyországban is lehet.

A magyar nyelv kedveli a hasonlatokat, gyakran használja öket. Az öröm kifejezését több hasonlat segítségével is érzékelteti. Itt kell megemlíteni, hogy a bánatot is az örül, mint kezdetü hasonlattal indítja, de a hasonlatok vége gúnyos, ironikus.

A bolgár nyelv nem használ gyakran hasonlatokat, az öröm kifejezésére azonban mégis elöfordulnak hasonlatok, amelyek az örömöt a napfénnyel és a meleggel kapcsolják össze. A bolgár ember sajátossága, hogy az örömét, lelkesedését, elragadtatását leplezni, titkolni próbálja.

$\mathrm{Az}$ érzelmek kifejezése tehát az adott érzelem kommunikációját segíti. Az érzelmek kifejezése összetett folyamat, a test számtalan megnyilvánulása részt vesz benne. Az érzelmeket, ahogy a frazeológia is bizonyítja, legszembetünőbben az arckifejezés tükrözi. Az arckifejezés mellett azonban érzelmekről árulkodik a testtartás és a gesztusok is. A hanglejtés, a beszédtempó és a hangszín szintén sok információt nyújthat a kommunikáció folyamatában (PSZICHOLÓGIAI).

\section{Irodalom}

BAŃCZEROWSKI 2005 = BAŃCZEROWSKI J. A félelem tartományába tartozó negatív érzelmek konceptualizációjáról // Magyar Nyelvőr, 2005. № 2. 202-208.

BARÁTKA 2014 = BARÁTKA A. Hogyan néz ki és hogyan viselkedik egy boldog magyar? 2014. december 1 .

http://www.fokusz.info/index.php?cid=1163529137\&aid=1677099891 
NAGY 1999 = NAGY P. Madarat lehet fogatni vele // Magyar Nyelv, Szó- és szólásmagyarázat, 1999, № 2. 203-206.

PSZICHOLÓGIAI = Pszichológiai elméleti alapok. Az érzelemről általában.

http://old.ektf.hu/hefoppalyazat/pszielmal/az_rzelemrl_ltalban.html

\section{Szótárak}

BÁRDOSI V. (főszerk.). Magyar szólástár. Budapest, 2003.

O. NAGY G. Magyar szólások és közmondások. Budapest, 1976.

T. LITOVKINA A. Magyar Közmondástár. Budapest, 2005. http://mek.oszk.hu/09100/09112/html/index.html

DUGONICS A. Magyar példabeszédek és jeles mondások. Szeged, 1820.

ERDÉLYI J. Magyar közmondások könyve. Pest, 1851.

MARGALITS E. Magyar közmondások és közmondásszerü szólások. Budapest, 1896.

SIRISAKA A. Magyar közmondások könyve. Pécs, 1891.

Български национален корпус. http://dcl.bas.bg/bulnc/

НИЧЕВА К. - СПАСОВА-МИХАЙЛОВА С. - ЧОЛАКОВА КР. Фразеологичен речник на българския език. Том първи А-Н. София, 1974

НИЧЕВА К. - СПАСОВА-МИХАЙЛОВА С. - ЧОЛАКОВА КР. Фразеологичен речник на българския език. Том втори О-Я. София, 1975.

НИЧЕВА К. Нов фразеологичен речник на българския език. София, 1993. 